\title{
Powrót do prawa naturalnego
}

\author{
DOI 10.35757/CIV.2016.19.17
}

Wojciech Dziedziak, O prawie stusznym (perspektywa systemu prawa stanowionego), Wydawnictwo Uniwersytetu Marii Curie-Skłodowskiej, Lublin 2015, ss. 309.

Książka jest ważnym głosem we współczesnej dyskusji na temat podstaw prawa. Prezentuje stanowisko prawa naturalnego oraz atakuje pozytywizm $z$ pozycji aksjologicznych, pośrednio krytykując tezę o rozdziale prawa i moralności. Praca sytuuje się też w opozycji do popularnych koncepcji realizmu prawnego, opartych na socjologii czy psychologii. Według Wojciecha Dziedziaka dobre prawo to takie, które spełnia wymogi zdefiniowanej przez autora „słuszności”", a nie, jak sądzą realiści - które znajduje odzwierciedlenie w powszechnych zachowaniach. Przyjęcie takiej orientacji ideowej jest ciekawe, zwłaszcza ze względu na fakt, że jest ona dużo mniej popularna wśród środowisk prawniczych. Podobna filozofię prawa prezentuje między innymi doktor habilitowana Tatiana Chauvin $z$ Uniwersytetu Warszawskiego ${ }^{2}$.

Innym kontrowersyjnym punktem wyjściowym jest bioetyka. Jedna ze składowych elementów pojęcia słuszności jest godność człowieka, rozumiana przez autora jako przynależna od momentu poczęcia do chwili naturalnej śmierci. Wobec coraz większej debaty dotyczaccej prawa aborcyjnego recenzowana pozycja może być ciekawa pod względem wykorzystania koncepcji bioetycznej do budowy systemu oceniajaccego normy prawne.

W ramach pracy autor poddaje analizie i wykorzystuje koncepcje słuszności opracowane przez Henryka Piętkę. Do innych

\footnotetext{
1 W. Dziedziak, O prawie słusznym (perspektywa systemu prawa stanowionego), Wydawnictwo Uniwersytetu Marii Curie-Skłodowskiej, Lublin 2015, s. 226-229.

2 Por. T. Chauvin, Homo iuridicus. Człowiek jako podmiot prawa publicznego, Wydawnictwo C.H. Beck, Warszawa 2014.
} 
często cytowanych autorów należą: Piotr Winczorek, Jerzy Stelmach, Marek Piechowiak, Marek Safjan, Tatiana Chauvin, ojciec Mieczysław Krapiec i Lech Garlicki. Przywoływane akty prawne pochodza głównie od agend ONZ oraz instytucji Rady Europy. Omawiana jest także nowelizacja kodeksu karnego, która miała wejść w życie 1 lipca 2015 roku. Należy podkreślić, że autor przygląda się aktom prawnym $z$ dużą wnikliwością, śledząc również dodatkowe sprawozdania czy wyjaśnienia do poszczególnych aktów, na przykład Konwencji o ochronie praw człowieka i godności istoty ludzkiej czy Karty Praw Podstawowych Unii Europejskiej.

Podstawowym pojęciem, na którym opiera autor swoja koncepcję, jest „słuszność”. Dziedziak ujmuje ja „substancjalnie”3, co oznacza, że pojęcie słuszności składa się z następujących elementów: prawda, dobro, sprawiedliwość i godność człowieka. Na tej bazie tworzy system opisujący podstawy aksjologiczne prawa, warunki jego stanowienia i stosowania. Analizuje również metaaksjologię Konstytucji RP i dokumenty międzynarodowe dotyczące praw podmiotowych, w celu wykazania, że zawierają one cechy prawa słusznego.

We wstępie autor zaznacza cel swojej pracy. Jest nim przedstawienie teorii prawa słusznego, a także wykazania jej prawdziwości. Koncepcja redakcyjna książki oddaje ten zamysł. Jest ona podzielona na pięć rozdziałów i w każdym $z$ nich prezentowane jest jedno zagadnienie, które później autor adaptuje do całej teorii. Poszczególne rozdziały to: (I) Filozoficzne i instytucjonalne przejawy słuszności, (II) Pojmowanie słuszności i prawa słusznego, (III) Wyznaczniki prawa słusznego w Konstytucji Rzeczypospolitej Polskiej z 1997 roku, (IV) Słuszność u podstaw tworzenia prawa i (V) Stuszność $w$ stosowaniu prawa. W pierwszym rozdziale autor omawia filozoficzne i instytucjonalne przejawy słuszności. Przywoływana jest grecka epieikeia, rzymskie aequitas oraz słuszności w teologii tomistycznej. Poruszany jest również aspekt instytucjonalny na przykładzie działaności rzymskiego pretora. Kolejny rozdział

3 W. Dziedziak, O prawie słusznym..., s. 57. 
poświęca substancjalnemu znaczeniu słuszności. Autor definiuje to pojęcie i omawia jego części składowe. Trzeci rozdział dotyczy opisu metaaksjologii norm konstytucyjnych oraz kwestii ich poznawalności. Ostatnie dwa rozdziały skupiaja się na słuszności w stosowaniu i tworzeniu prawa.

Argumentacja przeprowadzona $\mathrm{w}$ ten sposób sprawia, że praca jest spójna, a nadrzędna myśl przyświeca kolejnym rozdziałom. Brak dygresyjności umacnia logikę wywodu, ale $z$ drugiej strony zamysł ten powoduje, że część polemiczna i krytyczna jest bardzo zredukowana. Autor dyskutuje głównie ze współczesnymi bioetykami, takimi jak Peter Singer. Poddaje krytyce poszczególne interpretacje aktów prawa międzynarodowego, które pod pozorem ochrony praw podmiotowych dopuszczaja ich ograniczanie. Watki polemiczne skupione sa w rozdziale IV, w którym Wojciech Dziedziak broni podstawy swojej teorii - niepodważalnego prawa do życia od poczęcia. Poza tym jednak kwestie teoretyczne nie są rozstrzygane przez konfrontację $z$ poglądami innych filozofów. Wyjątkiem jest ostatnia część pierwszego rozdziału, w której autor relacjonuje koncepcję słuszności Henryka Piętki ${ }^{4}$, przedwojennego teoretyka prawa.

Wyłożona przez Wojciecha Dziedziaka teoria jest synteza koncepcji prawnonaturalnych, zawierajacych zapożyczenia między innymi $z$ personalizmu. Podstawowa kategorią, która przyjmuje charakter walidacyjny wobec prawa, jest słuszność. Słuszność w rozumieniu substancjalnym, co podkreśla autor, składa się ze wspomnianych już wartości: prawdy, dobra, sprawiedliwości i godności człowieka. Prawda jest rozumiana w sposób klasyczny: jako zgodność intelektu poznania i rzeczy ${ }^{5}$. Jako dobro przyjmowane jest dobro człowieka oraz dobro wspólne (warunki socjalne, konieczność prawa do życia) ${ }^{6}$. W odniesieniu do sprawiedliwości autor wielokrotnie przytacza definicję Ulpiana: „Sprawiedliwość

Ibidem, s. 31-35.

5 Ibidem, s. 58.

6 Ibidem, s. 64. 
polega na oddawaniu każdemu tego, co mu się należy"'. Dodaje jednak, że sprawiedliwość to też sfera respektowania należnych człowiekowi uprawnieñ ${ }^{8}$. Godność bezpośrednio jest definiowana jako godność osobowa9. Jest ona wrodzona i stanowi immanentną cechę bycia człowiekiem. Jest podstawa etyki uniwersalnej i dlatego jest odróżniona od godności osobowościowej, która autor postrzega jako źródło etyki relatywistycznej. Nie charakteryzuje jednak konkretnej cechy człowieczeństwa, która wyjaśnia, dlaczego akurat człowiek jest obdarzony godnością. W dalszej części pracy mówi otwarcie, że stoi na gruncie etyki personalistycznej ${ }^{10}$. Można więc domyślać się, że to zdolność poznania dobra i zła oraz możliwość czynienia sprawiedliwości, która jest trwale złączona $z$ dobrem, decyduja o naszej godności.

Autor zaznacza, że dobro powinno stanowić paradygmat tworzenia prawa, sugerując, że niesłuszne prawo nie istnieje, bo nie jest wtedy prawem. W bardzo interesujący sposób odnosi ten pogląd do słuszności w tworzeniu prawa. W rozdziale poświęconym temu zagadnieniu nie znajdziemy postulatów dotyczących działań prawodawczych czy samego ustawodawcy. Dziedziak koncentruje się na prawie do życia w odniesieniu do bioetyki. Określa ją jako główne zagrożenie dla prawa słusznego. W swoim wywodzie przekonywająco argumentuje za koniecznościa ochrony życia już od poczęcia. Poświęca wiele miejsca na analizę aktów prawa międzynarodowego dotyczacych wymienianych kwestii, głównie dokumentów ONZ i Rady Europy. Wskazuje też na niebezpieczne konsekwencje dla statusu osoby ludzkiej eksperymentów zwiąanych $z$ klonowaniem oraz krytycznie odnosi się do metody sztucznego zapłodnienia in vitro jako reifikującej godność człowieka. Wśród innych postulatów wymienia między innymi konieczność zapewnienia wszystkim osobom warunków umożliwiających realizację, w ramach spełniania dobra powszechnego. Wśród nich

7 Ibidem, s. 68.

8 Ibidem.

9 Ibidem, s. 72.

${ }^{10}$ Ibidem, s. 161. 
jest podniesiona kwestia odpowiedzialności karnej za wykroczenie przeciwko słuszności w procesie tworzenia prawa, ale autor nie rozwija tej koncepcji ${ }^{11}$. Pozostawienie w niewyjaśniony sposób tak znaczącego postulatu należy uznać za wadę książki.

Co do stosowania prawa autor zwraca uwage, że zapewniana przez akty prawne możliwość oddania każdej sprawy pod „sprawiedliwy" sąd nie precyzuje, o jaka sprawiedliwość chodzi. Dziedziak odpowiada, że nie może chodzić tu o sprawiedliwość pozytywistyczna, a więc gwarantowana tylko przez prawo materialne. Pisze, że chodzi o taka wykładnię, która dba o rzeczywiste dobro człowieka $^{12}$. W modelu dochodzenia do decyzji słusznej w procesie stosowania prawa autor powraca do rozważań $z$ pierwszego rozdziału, skłaniajacc się ku poglądom na temat wykładni zgodnej $z$ duchem powszechnej sprawiedliwości, ze słusznością. Sędziom poleca perfekcjonistyczne podejście w orzekaniu, co wiąże się między innymi $z$ odrzuceniem pragmatycznej zasady clara non sunt interpretanda ${ }^{13}$. Pozostawienie szerokiej sfery swobody władzy sadowniczej ma włączyć ją w realizację prawa słusznego, także przez korygowanie sprzeczności i wypełnianie luk, jeżeli występują. Kryteriami decyzji sa wartości, o których mowa w konstytucji ${ }^{14}$. Autor twierdzi, że te wartości są wystarczająco jasne, żeby orzec słuszna decyzję. Dziedziak nie pisze o możliwych negatywnych konsekwencjach udzielenia tak dużej władzy dyskrecjonalnej sędziom. Wydaje się, że autor uważa własna interpretację metaaksjologii za jasna i niedyskusyjna, co miałoby wystarczająco ograniczać działania sędziów. Nasuwaja się wątpliwości, czy to rozwiązanie zapewniłoby odpowiednia ochronę oraz czy w praktyce utrzymałaby się jedność sądów na temat wartości podstawowych dla orzeczeń.

Rozdziały poświęcone analizie norm konstytucyjnych oraz ochronie życia ludzkiego od poczęcia wyróżniaja się na tle pozostałych. W obu elementy teorii Wojciecha Dziedziaka sa prezentowane

11 Ibidem, s. 202.

12 Ibidem, s. 260.

13 Ibidem, s. 264.

${ }^{14}$ Ibidem, s. 250. 
na konkretnych przykładach ${ }^{15}$. Nie łamia one jednak ogólnej kompozycji wywodu, ale wzbogacaja go. Fragment poświęcony ochronie fazy prenatalnej w rozwoju człowieka skupia się na biologicznych argumentach świadczących o tym, że coś nie może się stać kimś i że jedynym słusznym rozwiązaniem tego sporu jest przyjęcie koncepcji życia ludzkiego od poczęcia ${ }^{16}$. Autor tak silnie akcentuje ten fragment swojej teorii, że stawia problemy bioetyczne ponad podziałem na konserwatyzm i postęp, ale lokuje go jeszcze wcześniej, jako sferę zupełnie podstawowa. Wymogiem prawa słusznego, jak twierdzi, jest oparte na godności istnienie człowieka. $Z$ drugiej strony poświęcenie takiej uwagi sferze biologicznej bez użycia metafizyki może prowadzić do interpretacji, według których $z$ samej biologicznej natury człowieka wynikaja wszelkie jego uprawnienia. Taka teza zdaje się nie współgrać $z$ główna, która przez cały czas opiera się na walidacyjnym charakterze pewnych zewnętrznych norm. Powstała w ten sposób nieścisłość może być polem do krytyki tezy autora.

Równie interesujący jest rozdział poświęcony analizie metaksjologii Konstytucji Rzeczypospolitej Polskiej ${ }^{17}$. Już przyjęcie spojrzenia metaaksjologicznego jest bardzo ciekawe i radykalizuje na przykład poglądy Trybunały Konstytucyjnego, który zaznaczał, że ustawa zasadnicza jedynie potwierdza istniejące prawa podmiotowe. Różnica polega na tym, że Trybunał Konstytucyjny ujmował te prawa w ramach aksjologii konstytucji, a Dziedziak posuną się o krok dalej, twierdzac, że to nie wartości takie jak wolność czy godność sa sfera konstytucji, ale to konstytucja raczej wkracza w sfery wartości i $z$ nich czerpie swoje inspiracje. Podstawowymi tezami autora w tej materii sa kognitywny charakter konstytucyjnych wartości, a także odejście od czysto pozytywistycznych interpretacji. W analizie konstytucji szczególnie podkreślana jest rola preambuły i przekazywanej za jej pomocą ratio legis aktów normatywnych.

${ }^{15}$ Ibidem, s. 188.

${ }^{16}$ Ibidem, s. 195.

${ }^{17}$ Ibidem, s. 79-111. 
Ciekawe wydaje się spojrzenia na recenzowana pracę pod kątem filozofii polityki. Autor nie przedstawia żadnych postulatów ustrojowych, co oczywiście nie jest sprawa książki. Jednak wprowadzanie bardzo konsekwentnej, perfekcjonistycznej, zanurzonej w myśleniu klasycznym i chrześcijańskim teorii w praktyce nie udałoby się $\mathrm{w}$ ramach konsensualnej demokracji. Teoria prawa słusznego nie pozostawia miejsca na kompromisy. Istotna wartościa jest życie, które uznane zostało za nienaruszalne od naturalnego poczęcia, a wszystko inne wynika właśnie $z$ tej wartości. Jeżeli tak, to wszelka modyfikacja konsekwencji wymaga pełnego przyjęcia postulatu ochrony życia, co w społeczeństwie demokracji konsensualnej byłoby nie do przyjęcia. $Z$ drugiej strony autor nie wyraża się w sposób negatywny ani o konstytucji, ani bezpośrednio o organach międzynarodowych. Krytykuje jedynie rezultaty ich działań. Pytanie o środowisko implementacji swojej teorii autor pozostawia otwarte. Interesujące jest również zdystansowanie się od podziału ideologicznego na konserwatyzm i liberalizm. Choć teorię prawa słusznego zdecydowanie można zaliczyć do teorii konserwatywnych, to autor stara się pominąć tę kategorię.

Niektórym czytelnikom może być trudno przyjąć książkę w proponowanej formie. Na pewno wybrzmiewa ona jednym głosem, nie ma charakteru dyskusji, ale wykładu. Sama teoria jest radykalna, silnie ugruntowana w wartościach klasycznych i chrześcijańskich. Jednocześnie powinna ona być dostrzeżona przez środowiska zwolenników teorii prawnonaturalnych. $Z$ praca Wojciecha Dziedziaka powinni się zapoznać przede wszystkim teoretycy prawa, ale również prawnicy praktycy, etycy, bioetycy oraz każdy, kogo interesuja aksjologiczne fundamenty współczesnego prawa. Filozofowie natomiast moga się przyjrzeć tej książce pod względem współczesnego tworzenia teorii $\mathrm{w}$ postaci całego systemu.

\section{Maksymilian Hau}

$\overline{\text { Maksymilian Hau - student Kolegium Artes Liberales Uniwersytetu Warszawskiego i Wy- }}$ działu Prawa i Administracji UW. 